\title{
Developing Macromedia Flash Teaching Material in the Topic of Negotiating Text for Muhammadiyah Vocational School in Magelang
}

\author{
Nur Rahma Wati \\ SMK Muhammadiyah Mungkid Jl. Pemandian-Blabak Magelang Indonesia \\ *Corresponding author, e-mail: nur06rahmawati@gmail.com
}

\begin{abstract}
The purpose of this study is to develop Macromedia Flash teaching materials to increase student learning outcomes and to determine the feasibility of Macromedia Flash-based teaching materials. This research is research and development ( $R$ \& D) using the 4D development model. This study involved subjects namely students of Grade X of Muhammadiyah Mungkid Vocational School and Salaman Muhammadiyah Vocational School. Data analysis uses quantitative data analysis. The analysis used was an independent sample t-test using SPSS version 17. The results of the development produced a product in the form of Macromedia Flash-based learning media on the subject of negotiation text for learning Bahasa Indonesia. The results of the research suggest that there are differences in the average score of student learning outcomes before and after using Macromedia Flash media. The percentage of students reaching the passing grade of 75 before using Macromedia Flash or conventional media is $9 \%$ and after using Macromedia Flash media to $68.3 \%$. The result of calculated-t value is 10.3 while the $t$-table is 1.657 . The $t$-test analysis proves that Macromedia Flash learning media is suitable for Bahasa Indonesia learning, especially on the subject of negotiation text. Moreover, the learning is more effective than using conventional learning media.
\end{abstract}

Keywords: Macromedia Flash, Negotiating text, Teaching materials.

\section{INTRODUCTION}

Education is a significant factor in the formation of the human person. Through education, various aspects of life are realized through the teaching and learning process. Multiple problems in the teaching and learning process need to be harmonized and stabilized so that the learning conditions are formed according to the goals to be achieved and can be obtained as optimally as possible (Kebudayaan, 2013).

Berulava (2013) states that the implementation of learning in vocational education focuses on practical learning. This is done because vocational education has links to the world of work or industry, so practical knowledge and training hold the key to equipping graduates to be able to adapt to employment.

Hasnah and Jufri (2015) explain language learning is learning to communicate and learn to write. The purpose of Indonesian language subjects is that students can communicate effectively and efficiently by applicable ethics, both verbally and in writing. The effectiveness of learning is illustrated by student achievement. Mansyur (2016) emphasizes the implementation of language learning packaged into four aspects of language skills, namely listening, reading, speaking, and writing skills. The four elements of language skills have become the foundation of learning ranging from elementary school to college level. Every teacher is always empowered to master the four aspects.

Nurhakim (2015) stated in his journal that learning Indonesian at the level of secondary education in class $\mathrm{X}$ had been compiled in various forms of text, both oral and written, by placing Indonesian as a vehicle for expressing feelings and thoughts. Multiple ways of presenting feelings and thoughts are explained in various types of texts. One of the books studied is the Negotiation Text. 
Learning to write negotiating texts is one of the skills students must master to be skilled in making decisions. Negotiating text writing learning has significant benefits to be known by students, namely to find out the meaning of negotiating texts, negotiating text objectives, negotiating text structures, negotiating text rules, negotiation processes, necessary negotiation skills, negotiating characteristics, and consulting text examples. The basic knowledge that has been described can be used as a reference in writing negotiating texts (Lewicki, 2012).

Negotiation can occur when two people meet to reconcile their different solutions to the same problem. They interact, behave in a variety of different ways, try to change the perceptions of each other using various forms of language, and recover from a crisis of mutually exclusive expectations. So that there is a standard solution, one of them gets what they want and part of what they want in return, and agrees to implement an agreed-upon thing (Kenedy, 2016).

Data in the Ministry of Education and Culture shows that the last three years of Indonesian language examinations from 2015 to 2018 have declined.

Table 1. Average Vocational Indonesian Examination Vocational High School

\begin{tabular}{|c|c|c|c|}
\hline 2015 & 2016 & 2017 & 2018 \\
\hline 68.39 & 71,80 & 68,66 & 63,80 \\
\hline \multicolumn{4}{|c|}{ Source: Puspendik Kemdikbud (2018) }
\end{tabular}

In 2015 the average value of Indonesian language was 68.39, while in 2016, the average cost of the Indonesian language was 71.80, and in 2017 the average amount of Indonesian was 68.66. In 2018 the average value of the Indonesian language obtained the lowest cost of 63.80. This means that in the last three years, the average cost of the Indonesian language has not met the Minimum Completion Criteria (KKM). The amount of $\mathrm{KKM}$ in Indonesian language subjects is 75 . This occurs because one of the supporters of teaching and learning activities still uses conventional methods and less exciting teaching materials. This makes students less mastered the material even there is no interest in learning Indonesian language learning material. (Durri et al., 2016).

Learning negotiating text writing requires interesting class interactions to encourage students to develop ideas. The media that is suitable for developing students' ideas is Macromedia Flash. Macromedia Flash was chosen because using Flash media material can consist of audiovisual, animation, and even games. Students can use it easily and attractively. This device consists of a series of components, namely symbols, buttons, levels, frames, and screens. Macromedia Flash can help people integrate various multimedia material, such as graphics, sound, and animation, making a short but precious form of content (Dongwei et al., 2016).

Maintaining a favorable attitude, providing facilities and infrastructure for dialogue between teachers and students to occur is the role of the teacher in the learning process. Motivating students to elaborate on their ideas and explain the concepts they believe in, the teacher asks to stimulate students' thinking and can master the subject matter and can accept different views and respect the opinions of students and apply variations in teaching methods that are appropriate to the learning objectives (Milovanovic, 2013 ).

This study aims to determine the development of Macromedia Flash teaching materials so that it is known to increase student learning outcomes and to assess the feasibility of Macromedia Flash-based teaching materials for class $\mathrm{x}$ students of Muhammadiyah SMK Magelang Regency.

Wati, N. R. (2019). Developing Macromedia Flash Teaching Material in the Topic of Negotiating Text for Muhammadiyah Vocational School in Magelang. Journal of Vocational Education Studies, 2(1), 55-60. DOI: https://doi.org/10.12928/joves.v2i1.832. 


\section{RESEARCH METHOD}

This study uses a 4D development model from Thiagarajan, namely defining, designing, developing, and distributing. Research time in odd semester 2018/2019 academic year, namely September to December 2018. This study involved subjects, namely students of class $\mathrm{X}$ at Muhammadiyah Mungkid Vocational School and Salaman Muhammadiyah Vocational School. This study uses data analysis techniques to test hypotheses, including the Normality Test and Homogeneity Test and Analysis of different tests with parametric statistics in the form of a t-test (independent sample t-test).

\section{RESULTS AND DISCUSSION}

Macromedia Flash on the subject of negotiating texts for class X SMK students was developed based on the 4-D model. The explanation of research results based on development steps is as follows.

\section{Define}

Researchers get some information about the problems that occur among them as long as learning takes place, the teacher explains more in front of the class, so students tend only to accept explanations and record the material provided by the teacher. The content is studied according to curriculum 13, the Negotiation Text. The tasks performed by students during the learning process are evaluating the negotiating text, explaining the negotiating book, analyzing the negotiating text, and constructing the negotiating version.

\section{Design}

The researcher designed a research instrument that would be used to support the implementation of limited trials. This design phase consists of several steps, namely the preparation of RPP and teaching materials, include material, media, and practice questions.

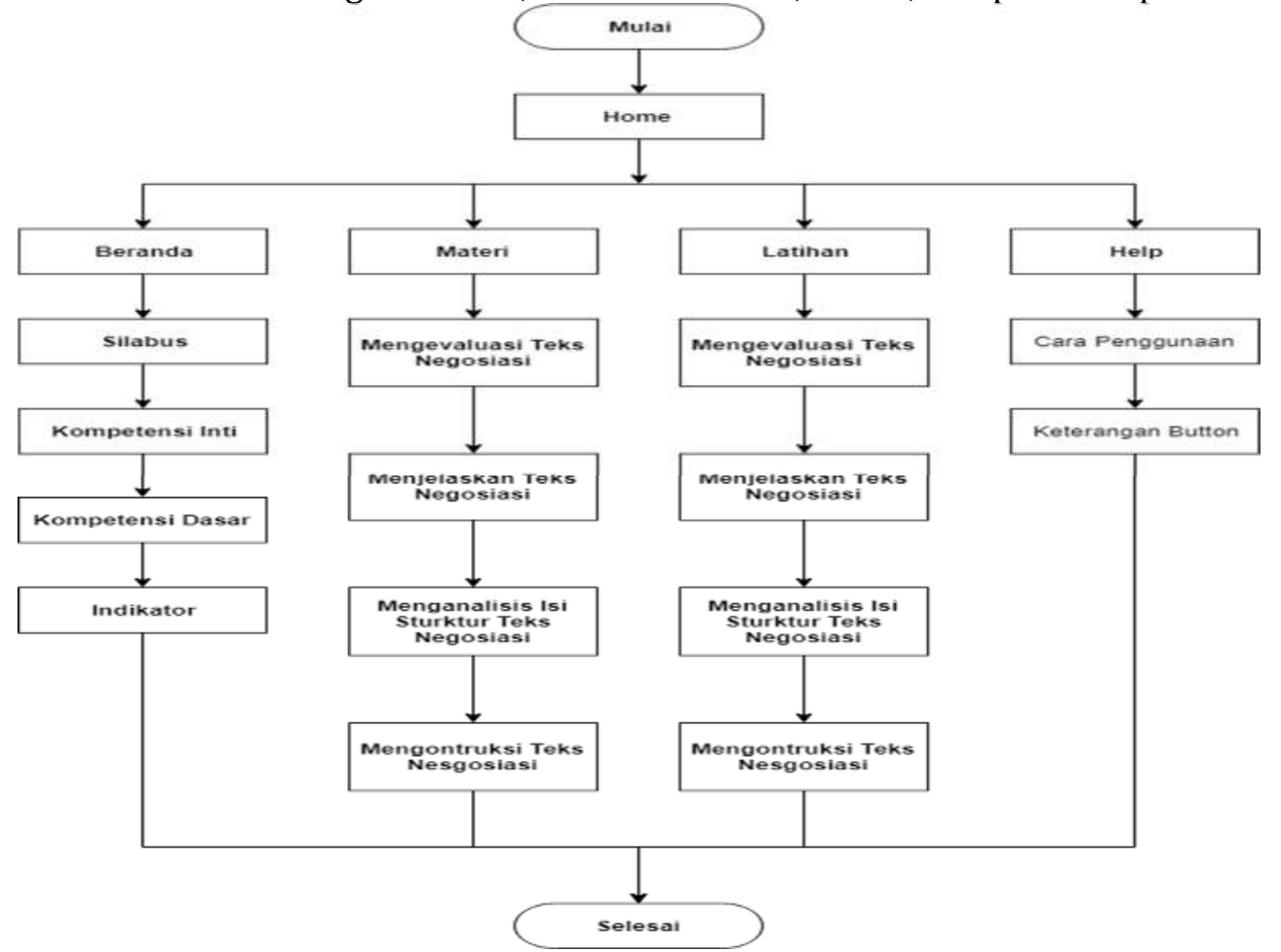

Figure 1. Steps for Media Compilation based on Macromedia Flash

Wati, N. R. (2019). Developing Macromedia Flash Teaching Material in the Topic of Negotiating Text for Muhammadiyah Vocational School in Magelang. Journal of Vocational Education Studies, 2(1), 55-60. DOI: https://doi.org/10.12928/joves.v2i1.832. 


\section{Development}

The purpose of the development phase is to produce revised learning media based on expert input and data obtained from the trial. Activities at this stage are expert assessments (validations), limited trials, and trials. Material experts who are experts, namely Dra. Marsilah and Dra. Muslimah, M.Pd., while media experts are Anggar Anugrah Satrya Wiratama, M.Kom.

The results of limited trials are presented in the following graph.

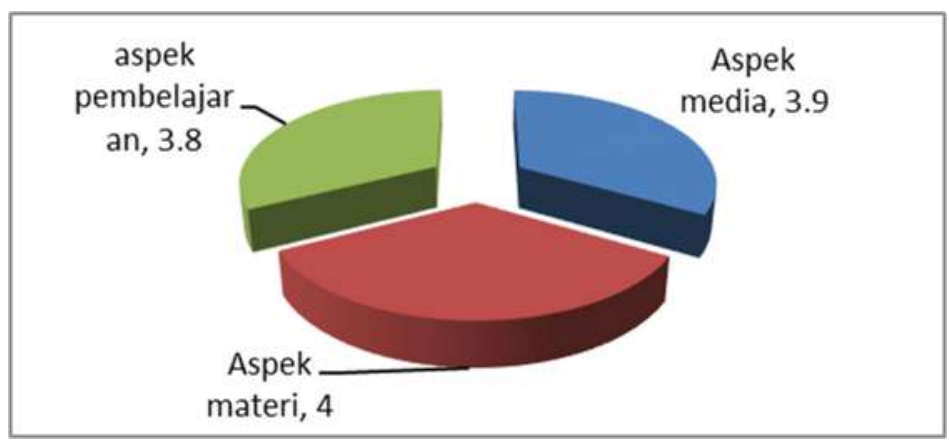

Figure 2. Limited Trial Results

The graph shows the media aspect gets a score of 3.9 or is in the Good category, a score of 4.0 or in the Good category on the material element, while the score is 3.8 or in the Good category on the learning aspect. While the overall average rating is 3.9 or entered in the Good category. So that it can be concluded all elements in the Good group.

Students looked enthusiastic and curious at the time of the trial. Students are also eager to learn even though the test is conducted at 9-10 or 13:00. The results of a comprehensive trial are presented in Figure 3.

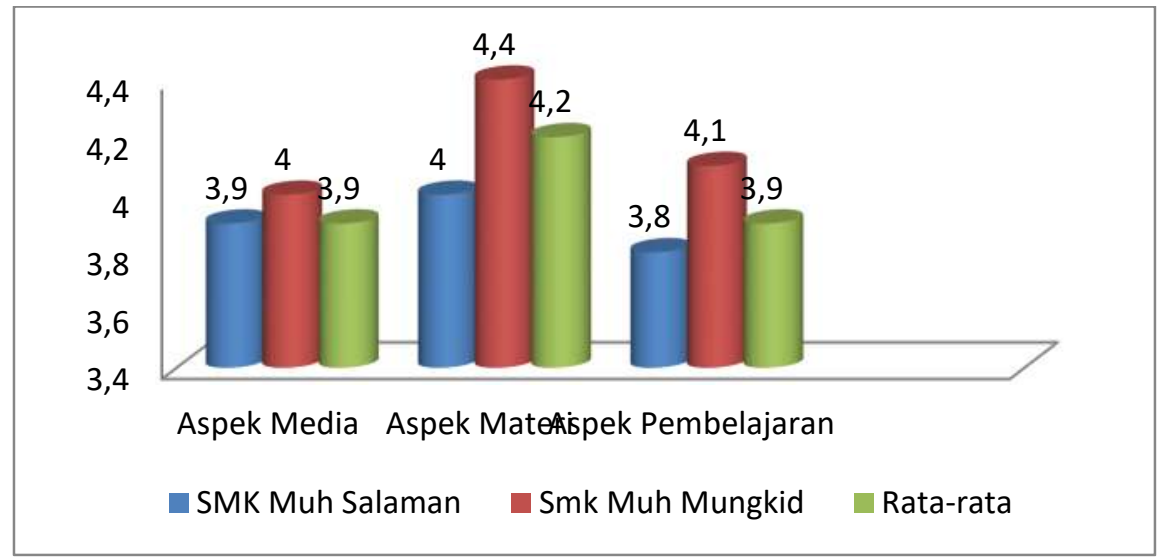

Figure 3. Comprehensive Trial Results

Figure 3 shows the results of a comprehensive trial conducted at Muhammadiyah Mungkid Vocational School and Salaman Muhammadiyah Vocational School. Viewed from the medial aspect, the results of the tests performed in two schools obtained scores that were not much different, namely at Muhammadiyah Mungkid 4 Vocational School and at Salaman Muhammadiyah Vocational School 3.9 So that the average rating gained when conducting a comprehensive trial on the media aspect is 3.9 which means in the Good 
category. The results of the average score obtained in the material elements tend to be much different because 0.4 is adrift. The results obtained at Salaman Muhammadiyah Vocational School are 4, while those in Muhammadiyah Mungkid Vocational School 4.4. So that the average score obtained is 4.2 , which means it is in a Good category. Whereas in the learning aspect, the average rating achieved is 3.9, which is in the Good category. This was obtained from the results of a comprehensive trial conducted in two schools, namely in Muhammadiyah Salaman Vocational High School, the score earned was 3.8, while in Muhammadiyah Mungkid Vocational School 4.1. It can be concluded that the results of a full trial in all aspects in the Good category.

\section{Disseminate}

This stage is the stage of deployment of devices that have been developed on a broader scale. The distribution is only done in a limited way, namely to provide Macromedia Flash products on the subject of the Negotiation Text to Indonesian Language teachers of the Muhammadiyah Vocational School in Magelang District in the form of learning CD.

Table 2. Results of Learning Media Testing

\begin{tabular}{cccccc}
\hline Media & N & Mean & F & Sig & $t$ \\
\hline MACRO & 63 & 79,25 &, 139 & 0 & 10,300 \\
Media Konvensional & 63 & 64,83 & & & \\
\hline
\end{tabular}

The data from the testing of learning hypothesis knowledge using Macromedia Flash media and conventional media shows the significance of the F test obtained 0.139 , thus the importance $>0.005(0.139>, 005)$ then it can be said that the data has the same variant. The result of the $t$ count is 10.300 , while the $t$ table is 1.657 . The value of $t$ count $>t$ table $(10,300>1,657)$ it is said that there is a significant difference between the use of Macromedia Flash media compared to conventional media.

T-test analysis shows the value of $t$ count is higher than $t$ table; thus, Ho is rejected, and $\mathrm{Ha}$ is accepted. The difference in the average cost of student learning outcomes before using Macromedia Flash or conventional media is 64.83, and after using Macromedia Flash media at 79, 25, so that it increases by 14.42 . The percentage of student learning outcomes above the KKM before using Macromedia Flash or conventional media by $9 \%$ and after using Macromedia Flash media to $68.3 \%$. The t-test analysis proves that Macromedia Flash learning media is suitable for use in Indonesian language learning, especially on the subject of Negotiation Text, besides education is more effective than using conventional learning media.

The products produced only contain one Indonesian language learning material, namely the subject of Negotiation Text. This study only applies to limited research subjects, namely Indonesian language teachers at Muhammadiyah Vocational School Magelang.

\section{CONCLUSION}

This research and development produce a product in the form of Macromedia Flashbased learning media on the subject of Negotiation Text for learning Indonesian X class X SMK. The steps are taken to produce learning media based on Macromedia Flash are as follows: a) deflation stage; b) design stage; c) development stage; and d) the deployment stage

Wati, N. R. (2019). Developing Macromedia Flash Teaching Material in the Topic of Negotiating Text for Muhammadiyah Vocational School in Magelang. Journal of Vocational Education Studies, 2(1), 55-60. DOI: https://doi.org/10.12928/joves.v2i1.832. 
T-test analysis shows the value of $t$ count is higher than $t$ table; thus, Ho is rejected, and $\mathrm{Ha}$ is accepted. The difference in the average cost of student learning outcomes before using Macromedia Flash or conventional media is 64.83, and after using Macromedia Flash media at 79, 25, so that it increases by 14.42. The percentage of student learning outcomes above the KKM before using Macromedia Flash or conventional media by $9 \%$ and after using Macromedia Flash media to $68.3 \%$.

The t-test analysis proves that Macromedia Flash learning media is suitable for use in Indonesian language learning, especially on the subject of Negotiation Text, besides education is more effective than using conventional learning media.

\section{REFERENCES}

Berulava, M. N., \& Berulava, G. A. (2013). The theory of networking education science and professional education. Moscow: Publishing House of the Russian Academy of Education.

Dongwei, Z., Qi, N., Tan, L., \& Zhang, S. (2016). Using flash software to make teaching courseware for analog electronics. International Conference on Education, Management, Computer and Society, 1590-1593. DOI: https://dx.doi.org/10.2991/emcs-16.2016.397.

Durri, A. A., Raharjo, H., \& Muchyidin, A. (2016). Applications of mathematics charged Islamic values by using Macromedia flash and Camtasia. ITEJ (Information Technology Engineering Journals), 1(1), 1-15.

Hasnah, S. \& Jufri. (2015). Pembelajaran menulis teks negosiasi melalui model pembelajaran berbasis masalah di SMA. Indonesia Journal of Educational Studies, 18(1), 50-57.

Kementerian Pendidikan dan Kebudayaan. (2013). Bahasa indonesia ekspresi diri dan akademik. Jakarta: Kementerian Pendidikan dan Kebudayaan.

Kenedy, G. (2016). Kennedy on negotiation. New York: Routledge.

Lewicki, R. J., Barry, B., \& Saunders, D.M. (2012). Negosiasi. Jakarta: Salemba Humanika.

Mansyur, U. (2016). Inovasi pembelajaran bahasa indonesia melalui pendekatan proses. Jurnal Retorika, 9(2), 90-163.

Milovanovic, M., Perisic, J., Vukotik, S., Bugarcic, M., Radovanovic, I., \& Ristic, M. (2016). Learning mathematics using multimedia in engineering education. Acta Technica Corviniensis- Bulletin of Engineering, IX(1), 45-49.

Nurhakim, M. (2015). Keefektifan model pembelajaran berbasis masalah dalam pembelajaran menulis eksposisi siswa kelas X SMK YPLP PGRI Makassar. Jurnal Pendidikan Pengajaran Bahasa dan Sastra ONOMA, I(1), 29-38. DOI: http://dx.doi.org/10.30605/onoma.v1i1.243.

\footnotetext{
Wati, N. R. (2019). Developing Macromedia Flash Teaching Material in the Topic of Negotiating Text for Muhammadiyah Vocational School in Magelang. Journal of Vocational Education Studies, 2(1), 55-60. DOI: https://doi.org/10.12928/joves.v2i1.832.
} 